\title{
Adversity and resilience: 10 lessons I have learnt from working with children in humanitarian emergencies
}

\author{
Lynne Jones ${ }^{1,2}$
}

\begin{abstract}
The war acquires comparatively little significance for children so long as it only threatens their lives, disturbs their material comfort, or cuts their food rations. It becomes enormously significant the moment it breaks up family life and uproots the first emotional attachments of the child within the family group.

Anna Freud and Dorothy Burlingham,
\end{abstract} $1943^{1}$

Being shelled is not the most upsetting thing that can happen to a child. Living in safety but being separated from your parents can be equally or more upsetting and have enduring effects on your mental well-being. I relearnt Freud and Burlingham's ${ }^{1}$ important lesson when researching the psychological effects of the Bosnian War (1992-1995) on children. Fikreta explained how:

\section{...We stayed at our grandparents' house for four years. ...I cried often because there was a lot of shooting there (Gorazde), so I was afraid something could happen to my parents. ... when I spoke with them I started to cry as soon as I heard their voices. Days passed, I was sad and nothing could make me happy. ${ }^{2}$}

She continued to feel unwell after the war, as did other children evacuated away from their parents. When I followed up 14 of those children 20 years later, including some who had suffered from post-traumatic stress disorder (PTSD) in 1998, the only one whose mental health was still problematic was a Serbian girl who had spent the war separated from her parents in Belgrade. She felt nervous, insecure and unhappy, and saw this as partly related to being forced to live away from her parents. Thus, she had given up a university course and returned to her home town to live with her family: I am filling in holes. I am trying to make up what I missed. ${ }^{2}$

${ }^{1}$ Fellow, FXB Center for Health and Human Rights, Harvard University, Cambridge, Massachusetts, USA ${ }^{2}$ Honorary Consultant, South London and Maudsley NHS Foundation Trust, London, UK

Correspondence to Dr Lynne Jones, FXB Center for Health and Human Rights, Harvard University, Cambridge, MA 02138, USA; lynnemyfanwy@gmail.com
Children are better off with those they love is the first of 10 lessons that children have taught me in the last 25 years of working with them in various humanitarian emergencies. This is not to suggest that we should not do our utmost to remove children from danger but rather that the removal should be in the company of those to whom they are closest. It is now well established that one of the key protective factors against the long-term negative effects of toxic stress is the availability of a responsive loving parent. ${ }^{3-5}$ This also means that family reunification should be a priority for unaccompanied children and institutionalisation should be avoided. This lesson has gained a particular significance given the recent crisis on the southern border of the USA, where more than 2000 children escaping violence in Central America have been separated from their parents with no plans for reunification, in an effort to deter illegal immigration. ${ }^{6}$

Unfortunately, not all families are loving ones and war may paradoxically provide some escape, as illustrated by Amela's story. In Bosnia I used lifelines to allow children to retrospectively describe their overall well-being during their lives. A dot against a scale from $1 \%$ to $100 \%$ for each year produces a line as in figure $1 .^{7}$

Most children interviewed in 1998 produced lines like G10, indicating that the war years had been the most unpleasant, but they had now recovered. Amela's line (G8) was different. The best years of her life were during the most intense phases of the siege of Gorazde, while the worst were before and after the war. The explanation: her father had been away fighting during the war, apart from one brief period of leave, freeing her mother from persistent emotional and physical abuse. Only when her parents divorced did things begin to improve again. ${ }^{2}$ Catherine Panter-Brick and her colleagues ${ }^{8}$ studying displaced children in Afghanistan also found that family violence was a key predictor of mental health outcomes even in the context of long-term militarised conflict. Miller and Jordans ${ }^{9}$ found that intrafamily violence may be a significant mediator in the relationship between armed conflict and children's mental health. Lesson 2: violence inside the family may be as damaging to long-term mental health as violence outside.

The tragedy is that war and displacement can increase the stresses that contribute to family violence. These Syrian refugee children living in a camp in Northern Greece, whom I interviewed in 2016, complained that camp life had changed their parents' behaviour and physical punishments had increased:

\begin{abstract}
...When I was young my mother never hit me, she taught me good and bad by talking. When we came here, when I do bad things she hits me. (Girl, 8-12 years)

...I see a little violence, because if I go and fight with another boy my father will hit me, he never did that in Syria. If I leave the tent without permission and come back, he will hit me. (Boy, 12-14 years)
\end{abstract}

The increase in violence within the family was one of the many complaints they had about their current lives, when

Figure 1 Examples of lifelines drawn by primary school girls in Gorazde in 1998.

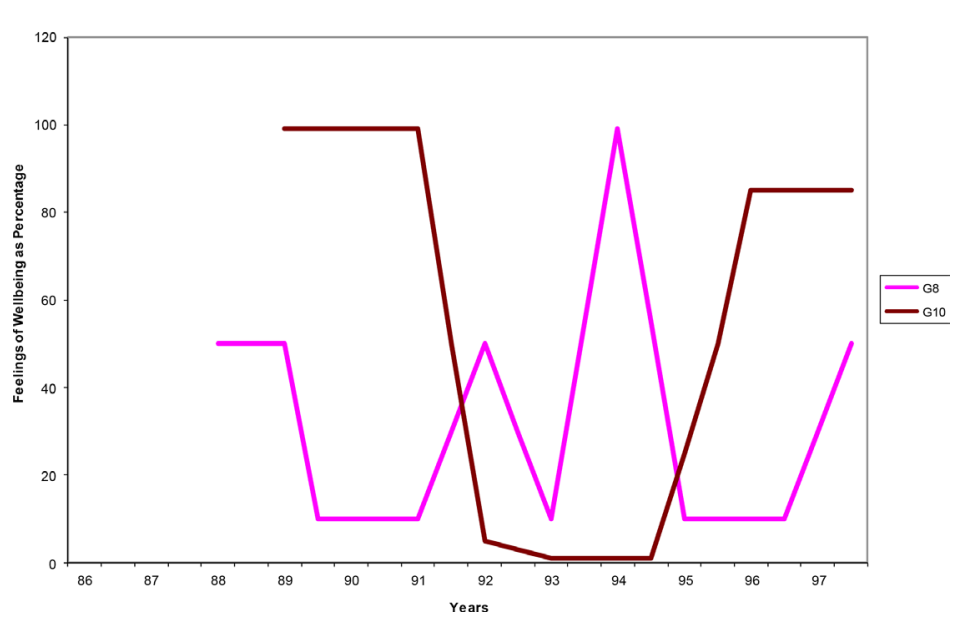


they were asked what bothered or upset them most. Other problems were fights in the camp, lack of clean water, the lack of school, sexual harassment and fear of kidnapping. ${ }^{10}$ When I interviewed internally displaced Kurdish teenagers, living in Northern Iraq in 2003, and asked what bothered and upset them most, they did not mention the five previous conflicts that had taken place in their short lifespans. They complained of the toxic waste and unexploded mines that deprived them of places to play, the violence and discrimination they experienced, poverty, fear of failing at school and being beaten, and work. ${ }^{11} 12$ The feelings such conditions engendered are caught by this boy:

I would like to die, I don't have anything to do when I am not working. My life is too hard, I just want to die. I have thought of it (suicide) a couple of times. I don't do it because it would upset my parents and I know they need me. (Teenage boy, Takya camp, 2003)

This brings me to lesson 3: the problems of the present can often outweigh the traumatic experiences of the past and need to be addressed. A growing amount of research shows that the persistence and accumulation of adverse experiences such as child maltreatment, neglect and poverty in a child's life have profound effects on both physical and mental health throughout the life course. ${ }^{13}$

However note lesson 4: the impact of war and displacement is different for boys and girls. ${ }^{14} \mathrm{~A}$ teenage girl interviewed in the same Kurdish camp told me:

I am 13. I wake at seven, eat breakfast and do my jobs like washing the floor and doing the dishes. Then I collect wood, every other day. It's a long walk to find any. It can take four to fivehours and is very hard. When I get home, I am so hot so I wash my face but the water is hot as well and it's not refreshing. Ice is very expensive. I may help with the cooking. Then there is nothing to do so I just sit around. We cannot go out. I have never been to school. I cannot read or write. My elder sister went until sixth grade. She speaks Arabic and Kurdish. My brother is in second grade. I feel very sad. (Teenage girl, Takya camp, $2003^{12}$ )

The girls were just as unhappy as the boys that I interviewed, but their sadness resulted from confinement and lack of education, as well as domestic workload. A recent study in Syria showed that $35 \%$ of Syrian girls/women refugees are reportedly married before the age of 18 , compared with $13 \%$ in prewar Syria, and they are particularly vulnerable to harassment and sexual violence:
...I was 12 years old when we were displaced to Lebanon. After we arrived, I was sexually harassed by an older man. When my parents found out about this they forced me to get married. Now I have a child and I am pregnant and so unhappy. ${ }^{15}$

How are this young girl's/mother's needs best addressed? The answer is in lesson 5: we have to rethink what childhood means and respect how children conceptualise themselves. Girls who become mothers at 15 are entitled to all the rights and protections granted to any child under international law, such as the Convention on the Rights of the Child, but their needs are quite specific and different from other children who are not mothers. The needs of unaccompanied children are different again. Congolese and Rwandan orphans in camps in Western Uganda, whom I interviewed in 2007, complained of being given adult responsibilities they could not handle. For example, they could not make the monthly food ration last for the proper time and so went hungry ${ }^{16}$ :

\begin{abstract}
...We don't have an old person to take care of us. We leave late for school. It is difficult to get meals ready. We have to cultivate for others to earn money and interrupt school to do it... hands are blistered from work. (Orphan refugee boy, Western Uganda, 2006)
\end{abstract}

In contrast some orphan children may develop extraordinary maturity and resilience: Sadiq fled war in his village in Somalia when he was 7 years old and arrived alone in Jijiga, in Ethiopia, where he had to work out how to survive:

\begin{abstract}
...Some people say they want shoe cleaning. So, I see one man with a car and I say I want to help, and the man says 'Ok' and gives me some water and I clean his car and he gives me some money, and I go to a shop and buy some stuff to clean shoes. When people have seen what I have seen, it makes you older than your age. Because I was small and I did not have a mother or a father, so I had to be my own mother and father. I went to the market and found people who could help me. So, every day I was in the market cleaning shoes and cleaning cars all day and I kept all the money from cleaning. I saved as much as I could and only used a little for the food and the house. I did this for another year until I was nine years old. After that I could buy clothes and I took a house alone.
\end{abstract}

Sadiq went on to work in three jobs, helped two Somali child friends who joined him and saved money for his family. When interclan fighting made his life dangerous in Jijiga, aged 13, he made the perilous journey across East Africa to Libya, survived a year's beating and imprisonment, and finally crossed to Italy. When I met him, he lived in a community home, attended school, had friends and dreamed of being a mechanic. But what preoccupied him most was how to send money to his mother in Somalia.

I have peace here... but later... I think all the time about how to help my family. Everything is not as it appears to you. I look OK but I am not. I have house, food, somewhere to sleep, but my family don't have food to eat, but if I go to Switzerland or Germany I can send money. I can do something if I go to Germany.

He could not enjoy being a child when he felt he had adult responsibilities. This was not recognised by those taking care of him in Italy, and so he left the home and travelled North. ${ }^{17}$

Sadiq was happy to talk to me at length and tell me his life story. But not all children want to share their experiences. If, how and when they do so is up to them. There is now an international consensus that forcing children to share their thoughts and feelings about their traumatic experiences or losses does not benefit them and may in some cases do harm. ${ }^{18} 19$ Lesson 6: do not force children to talk about their experiences if they do not wish to do so, but be able to listen if they $d o$, is important, but again not new: Anna Freud noticed that most children in her wartime London nursery never discussed either their losses or frightening events, for months or even a year after these had occurred. They then might suddenly recount it as if it had happened yesterday.

...In all these instances speech does not serve as an outlet for the emotion which is attached to the happening. It is rather the other way round. The child begins to talk about the incident when the feelings which were aroused by it have been dealt with in some other manner. ${ }^{1}$

Children who do not wish to talk about their experiences in conventional therapy may well choose to do so in another setting. After the Kosovo conflict I worked with five children aged between 5 and 14 at that time, who had witnessed and survived the brutal gunning down of 14 members of their extended family. Only one girl wanted to talk to me about what happened. One of the boys had talked at length to the press and did not want to repeat it. The other three did not want to talk at all. However, when offered the opportunity to testify to the War Crimes Tribunal, all the children wanted to be interviewed. A year later, when one of the perpetrators was put on trial in Belgrade, all the children recounted their experiences in detail in court and were glad to do so. ${ }^{12}$ It was a powerful demonstration of lesson 7: justice may be therapeutic. 
Unfortunately, the media focus on traumatic reactions to war and disaster has obscured the mental health needs of other groups of children, particularly those with developmental delay, epilepsy and severe mental disorders. There has been little research into the prevalence of these conditions in humanitarian settings. ${ }^{20} 21$ Most epidemiology has focused on PTSD and depression. ${ }^{22} 23$ Such children are not always easy to find and few resources are available for their protection or treatment. In Haiti after the earthquake, a child with severe developmental delay was left tied to her chair in an informal camp in the mental hospital yard being fed and nursed by her grandmother for weeks, because none of the agencies, including my own, had the capacities to address her profound needs. ${ }^{17}$ In Chad, I found a 13-year-old Darfuri girl with psychosis and malaria living chained in a pigsty. ${ }^{24}$ Lesson number 8: we need to seek out and address the needs of the most vulnerable children means that mental health practitioners in emergencies need the resources, skills and medications to address the needs of such children. It is a key responsibility as no one else is addressing it.

Vulnerable children include those under 3 years of age. Lesson 9: don't forget infants. We now know that sensitive and responsive parenting in early childhood, including play and stimulation, are as vital to infant development as good nutrition and are major protective factors against toxic stress. ${ }^{25}$ When mothers are stressed or depressed by adversity, the infant can suffer, as illustrated by this displaced young mother whom I interviewed in Northern Uganda in 2006. She told me of her own suicidal feelings because of the abuse she had suffered from her husband and the impact it had on her relationship with her child:

I can sleep in the evening but wake about midnight $1 \mathrm{am}$ because I think a lot and sleep does not easily come to eyes. I feel like I am losing weight. ...Sometimes I feel hopeless. Sometimes I think I should take my life other times I think I should not. Last year I told myself it is useless to end my life I should go back home. But if I go home he will still come for me, he will still come. (20-year-old displaced Ugandan mother)

Her distress clearly affected her relationship with her infant:

...I beat him and show him what he has done is bad. Some days I don't beat him other days I do. Sometimes I just beat him and then talk, others I talk first and then beat. If it is extra bad I beat straight away. Or if he does not listen or for example if he scatters things and makes the water in pot dirty. ...I don't tell stories to my children I knew some, I have forgotten. ...I don't play with my two-year-old. No one plays with him. I don't have it in my head to really play. I just don't want to play and it looks awkward for a big person to play. He does not play with his friends when he goes he fights with them and comes back crying. ${ }^{26}$

Yet such problems can be addressed with relatively simple interventions to support and enhance responsive parenting through home visits and parent baby groups. ${ }^{27-30}$ There is now increasing awareness of the need to develop such interventions. ${ }^{31} 32$

As will be clear from the above, every child is different, as is every context. It is almost impossible to make generalisations about emergencies because the needs of a teenage Eritrean refugee who has crossed two continents to try and reach the UK, been imprisoned in Libya and who now sleeps on the streets of Calais where he is peppersprayed by French Police each night ${ }^{33}$ are different from those of a child sheltering from bombing with her family in a basement in Syria. ${ }^{34}$ Context matters: both the intimate and the wider social world of the child. $^{22}{ }^{35}$ So lesson 10 is the most important one: listen to the child's voice. If given the chance they will tell you in their own way what matters to them, what bothers them and what they need to put it right. There is no better way to find out.

\section{Funding None declared.}

\section{Competing interests None declared.}

Patient consent Not required.

Provenance and peer review Commissioned; internally peer reviewed.

(c) Author(s) (or their employer(s)) 2019. No commercial re-use. See rights and permissions. Published by BMJ.

\section{Check for updates}

To cite Jones L. Arch Dis Child 2019;104:833-836.

Received 27 March 2018

Revised 10 July 2018

Accepted 17 July 2018

Published Online First 13 August 2018

Arch Dis Child 2019;104:833-836.

doi:10.1136/archdischild-2017-314038

\section{REFERENCES}

1 Freud A, Burlingham DT. War and Children. New York: Willard, 1943

2 Jones L. Then They Started Shooting: Children of the Bosnian War and the Adults They Become. New York: Bellevue Literary Press, 2013.

3 Franke HA. Toxic stress: effects, prevention and treatment. Children 2014;1:390-402.

4 Johnson SB, Riley AW, Granger DA, et al. The science of early life toxic stress for pediatric practice and advocacy. Pediatrics 2013;131:319-27.

5 Miller-Lewis LR, Searle AK, Sawyer MG, et al. Resource factors for mental health resilience in early childhood: An analysis with multiple methodologies. Child Adolesc Psychiatry Ment Health 2013;7:6-23.
6 Wan W. What separation from parents does to children: 'The effect is catastrophic'. The Washington Post. https:// www.washingtonpost.com/.separation./c00c30ec-732c11e8-805c-4b67019fff (accessed 23 Jun 2018).

7 Jones L, Kafetsios K. Assessing adolescent mental health in war-affected societies: the significance of symptoms. Child Abuse Negl 2002;26:1059-80.

8 Panter-Brick C, Goodman A, Tol W, et al. Mental health and childhood adversities: a longitudinal study in Kabul, Afghanistan. J Am Acad Child Adolesc Psychiatry 2011:50:349-63.

9 Miller KE, Jordans MJ. Determinants of children's mental health in war-torn settings: Translating research into action. Curr Psychiatry Rep 2016;18:58.

10 Jones L. Ethnographic assessment of psychosocial needs of children at Vasilika camp: International Medical Corps, 2016. https://internationalmedical corps.org/document.doc?id=801

11 Jones L. Supplementary report on IDPS living in hard shelters in Erbil and Dahuk Governorates: Unpublished report, International Medical Corps, 2003.

12 Jones $L$. Responding to the needs of children in crisis. Int Rev Psychiatry 2008;20:291-303.

13 Hughes K, Bellis MA, Hardcastle KA, et al. The effect of multiple adverse childhood experiences on health: a systematic review and meta-analysis. Lancet Public Health 2017;2:e356-e366.

14 Buvinic M, Das Gupta M, Casabonne U, et al. Violent conflict and gender inequality: an overview. Washington DC: World Bank, 2013. http://documents.worldbank.org/curated/en/ 270811468327340654/Violent-conflict-and-genderinequality-an-overview

15 Bartels SA, Michael S, Roupetz S, et al. Making sense of child, early and forced marriage among Syrian refugee girls: a mixed methods study in Lebanon. BMJ Glob Health 2018;3:e000509.

16 Jones L. Report on mental health needs assessment. Uganda: Unpublished report, International Medical Corps, 2007.

17 Jones L. Outside the Asylum: a Memoir of War, Disaster and Humanitarian Psychiatry. London: Weidenfeld and Nicolson, 2017

18 World Health Organisation. Guidelines for the management of conditions specifically related to stress. Geneva:WHO, 2013 http://www.who.int/ mental_health/emergencies/stress_guidelines/en/

19 World Health Organisation, United Nations High Commission for Refugees. Assessment and management of conditions specifically related to stress, MhGAP intervention guide module. Geneva: WHO, 2013 http://apps.who.int/iris/bitstream/ handle/10665/85623/9789241505932_eng.pdf? sequence $=1$

20 Jones L, Asare JB, El Masri M, et al. Severe mental disorders in complex emergencies. Lancet 2009:374:654-61.

21 Jones L, Rrustemi A, Shahini M, et al. Mental health services for war-affected children: report of a survey in Kosovo. Br J Psychiatry 2003;183:540-6.

22 Tol WA, Song S, Jordans MJ. Annual research review: resilience and mental health in children and adolescents living in areas of armed conflict-a systematic review of findings in low- and middle-income countries. J Child Psychol Psychiatry 2013:54:445-60.

23 Attanayake V, McKay R, Joffres M, et al. Prevalence of mental disorders among children exposed to war: a systematic review of 7,920 children. Med Confl Surviv 2009:25:4-19.

24 Jones L. The dispossessed: diary of a psychiatrist at the Chad / Sudan border (2004). Intervention 2011;9:364-72 https://www.interventionjournal.com/ sites/default/files/Jones_2011_Int_The_dispossessed_ diary_Chad.pdf

25 Shonkoff JP, Garner AS. The lifelong effects of early childhood adversity and toxic stress. Pediatrics 2012;129:e232-46. 
26 Jones L. Report of Acholi child rearing practices in the IDP camps of the Kitgum district, northern Uganda: Unpublished report, International Medical Corps, 2007.

27 Walker SP, Chang SM, Powell CA, et al. Effects of early childhood psychosocial stimulation and nutritional supplementation on cognition and education in growth-stunted Jamaican children: prospective cohort study. Lancet 2005;366:1804-7.

28 Engle PL, Black MM, Behrman JR, et al. Strategies to avoid the loss of developmental potential in more than 200 million children in the developing world. Lancet 2007;369:229-42.
29 Morris J, Jones L, Berrino A, et al. Does combining infant stimulation with emergency feeding improve psychosocial outcomes for displaced mothers and babies? A controlled evaluation from northern Uganda. Am J Orthopsychiatry 2012;82:349-57.

30 UNICEF and WHO. Integrating Early Childhood Development (ECD) Activities into Nutrition Programmes in Emergencies: Why What and How: UNICEF, 2011. http://www.who.int/mental_health/ emergencies/ecd note.pdf?ua=1

31 The Lancet. Advancing early childhood development: from science to scale: An executive summary for the Lancet's series. $2016 \mathrm{https}$ ://www.thelancet.com/
pb-assets/Lancet/stories/series/ecd/Lancet_ECD Executive_Summary.pdf

32 Black MM, Walker SP, Fernald LCH, et al. Early childhood development coming of age: science through the life course. Lancet 2017;389:77-90.

33 Jones L, Pye L. Yonas' story. https://www.migrantchild storytelling.org/yonas-story/

34 Jones L, Pye L. Maria's story. https://www.migrantchild storytelling.org/marias-story/

35 Barber BK. Annual research review: the experience of youth with political conflict - challenging notions of resilience and encouraging research refinement. J Child Psychol Psychiatry 2013;54:461-73. 